\title{
Penanganan Pencilan pada Data Deret Waktu menggunakan Metode Pemulusan Holt dan Robust Holt ${ }^{*}$
}

\author{
Septanti Kusuma Dwi Arini ${ }^{1}$, Farit Mochamad Afendi ${ }^{2 \ddagger}$, Pika \\ Silvianti ${ }^{3}$
}

\author{
1,2,3 Department of Statistics, IPB University, Indonesia \\ ‡corresponding author: fmafendi@apps.ipb.ac.id
}

\begin{abstract}
Copyright (C 2021 Septanti Kusuma Dwi Arini, Farit Mochamad Afendi, and Pika Silvianti. This is an open-access article distributed under the Creative Commons Attribution License, which permits unrestricted use, distribution, and reproduction in any medium, provided the original work is properly cited.
\end{abstract}

\begin{abstract}
Data deret waktu yang digunakan adalah data deret waktu mengikuti model LLTM (local linear trend model) dengan empat kondisi galat yang berbeda. Kondisi tersebut yaitu Clean Data (CD), Symmetric Outliers (SO), Asymmetric Outliers (AO) dan Fattailed data $(\mathrm{FT})$. Data deret waktu tersebut mengandung pencilan simetrik dan asimetrik yang dapat memengaruhi peramalan. Metode peramalan yang digunakan untuk pola data tren yaitu metode pemulusan Holt. Peramalan data deret waktu berpencilan menggunakan metode pemulusan Holt belum cukup baik sehingga diperlukan penangan dengan metode pemulusan robust Holt. Metode pemulusan robust Holt yang dilakukan pada data simulasi deret waktu lebih baik digunakan untuk kondisi data berpencilan dibandingkan dengan metode pemulusan Holt. Hal tersebut ditunjukan dari nilai evaluasi kebaikan metode, yaitu nilai MAD (Mean Absolute Deviation) yang dihasilkan. Nilai MAD untuk data training kondisi CD yang lebih kecil adalah metode pemulusan Holt, sedangkan untuk data testing metode pemulusan Holt dan robust Holt hampir sebanding. Kondisi SO untuk data training dan data testing nilai MAD yang lebih kecil adalah metode pemulusan robust Holt. Kondisi $A O$ untuk data training dan data testing nilai MAD yang lebih kecil adalah metode pemulusan robust Holt. Selain itu, nilai MAD pada kondisi FT untuk data training maupun data testing didapatkan hasil yang hampir sebanding diantara kedua metode.
\end{abstract}

Keywords: pencilan, data deret waktu, Holt smoothing, Robust Holt smoothing.

\footnotetext{
* Received: Dec 2018; Reviewed: May 2021; Published: May 2021
} 


\section{Pendahuluan}

Data deret waktu merupakan serangkaian data yang diamati dari suatu peubah berdasarkan urutan waktu dengan rentang yang sama (jam, hari, minggu, bulan, atau tahun). Secara umum, pola data deret waktu terdiri dari empat pola, yaitu pola data konstan, tren, musiman, dan siklik. Pola data tren terjadi apabila adanya kenaikan atau penurunan jangka panjang dalam data. Pola data deret waktu yang digunakan pada penelitian ini adalah pola data tren. Teknik pemulusan yang digunakan pada data deret waktu pola tren adalah metode pemulusan eksponensial. Metode pemulusan eksponensial merupakan teknik sederhana untuk menghaluskan dan meramalkan data deret waktu tanpa perlu menggunakan model parametrik. Metode Holt disebut juga sebagai metode pemulusan eksponensial ganda. Metode tersebut merupakan pengembangan dari metode pemulusan eksponensial untuk data deret waktu dengan pola tren.

Metode pemulusan eksponensial tidak bersifat kekar terhadap pencilan. Apabila data deret waktu terdapat pencilan maka hasil pemulusan dan peramalan menjadi kurang akurat. Pencilan dapat memengaruhi estimasi parameter dan peramalan ketika menggunakan metode pemulusan eksponensial karena nilai-nilai pemulusan dipengaruhi nilai-nilai sebelum dan sesudah dalam deret termasuk pencilan (Koehler et al., 2012). Selain itu, pemilihan parameter yang digunakan memengaruhi hasil peramalan dalam mengatur tingkat pemulusan. Parameter tersebut dipilih untuk meminimalkan jumlah kuadrat error dari peramalan. Salah satu pendekatan yang dapat digunakan untuk mengatasi pencilan adalah pendekatan pemulusan robust eksponensial.

Metode pemulusan robust Holt membuat pemulusan dan pemilihan parameter yang kekar terhadap pencilan. Algoritma pemulusan tersebut berdasar pada mekanisme pre-cleaning untuk pengidentifikasian dan pemberian bobot pada nilai pencilan. Pre-cleaning data dilakukan khusus untuk data deret waktu yang tidak stasioner sehingga secara signifikan dapat meningkatkan hasil peramalan. (Gelper et al., 2010) menyebutkan bahwa upaya pre-cleaning data pertama dilakukan oleh (Cipra, 1992), menyajikan metode Holt-Winters dengan pendekatan regresi terboboti. Usulan lain dibuat oleh (Kirkendall, 1992) sebuah metode untuk mengklasifikasikan setiap pengamatan sebagai pencilan atau level shift. Selain itu, (Taylor, 2007) mengusulkan menggunakan regresi kuantil untuk mendapatkan peramalan yang kekar. Oleh karena itu, penelitian ini menggunakan metode pemulusan Holt yang kekar terhadap pencilan dengan pendekatan prosedur robust pre-cleaning data, pemilihan parameter pemulusan, nilai awal, dan estimasi skala. Penelitian ini bertujuan menangani pencilan pada peramalan data deret waktu menggunakan metode pemulusan robust Holt dan membandingkan metode pemulusan Holt dengan pemulusan robust Holt pada kondisi pencilan yang berbeda. 


\section{Metodologi}

\subsection{Data}

Data yang digunakan pada penelitian ini adalah data simulasi menggunakan program R 3.5.1. Data simulasi ini merupakan pembangkitan $y_{t}$ data deret waktu 1000 kali pengulangan sebanyak 105 data deret waktu dengan 100 data amatan dan data peramalan pada data ke-101 sampai dengan 105. Pemberian data pencilan untuk setiap metode pemulusan Holt dan robust Holt terbagi menjadi empat kondisi pada galat (Tabel 1). Pemberian pencilan tersebut dilakukan dengan kondisi yang simetrik dan tidak simetrik pada deret dengan peluang adanya pencilan dalam data deret waktu sebesar $5 \%$, kemudian dibandingkan dengan deret yang tidak mengandung pencilan untuk setiap model.

Tabel 1: Galat pembangkitan data deret waktu

\begin{tabular}{lll} 
CD & Clean data & $e_{t} \sim N(0,1)$ \\
SO & Symmetric outliers & $e_{t} \sim(1-\varepsilon) N(0,1)+\varepsilon N(0,20)$ \\
AO & Asymmetric outliers & $e_{t} \sim(1-\varepsilon) N(0,1)+\varepsilon N(20,1)$ \\
FT & Fat-tailed data & $e_{t} \sim t_{3}$ \\
\hline
\end{tabular}

\subsection{Prosedur Analisis Data}

Tahapan analisis data yang dilakukan adalah sebagai berikut (Cipra, 1992; Croux et al., 2008; Gelper et al., 2010; Montgomery, 2007):

1. Pembangkitan data simulasi

Pembangkitkan data simulasi berdasarkan model Model LLTM (local linear trend model) menetapkan nilai yang teramati $y_{t}$ terdiri atas nilai level $l_{t}$ dan tren $t_{t}$ sebagai berikut:

dengan

$$
y_{t}=l_{t}+e_{t}, \quad e_{t} \sim N\left(0, \sigma^{2}\right)
$$

$$
\begin{aligned}
l_{t} & =l_{t-1}+t_{t-1}+\eta_{t}, & & \eta_{t} \sim N\left(0, \sigma_{\eta}^{2}\right) \\
t_{t} & =t_{t-1}+v_{t}, & & v_{t} \sim N\left(0, \sigma_{v}^{2}\right)
\end{aligned}
$$

dimana $e_{t}$ adalah galat yang mengikuti sebaran normal baku, $l_{t}$ adalah nilai level, $\eta_{t}$ adalah galat level, $t_{t}$ adalah nilai tren, dan $v_{t}$ adalah galat tren. Galat pada LLTM mengikuti sebaran normal baku serta $\sigma_{\eta}^{2}$ dan $\sigma_{v}^{2}$ sebesar 0.1 .

2. Peramalan data deret waktu.

Peramalan yang digunakan adalah metode pemulusan Holt dan metode pemulusan robust Holt. Model untuk metode pemulusan Holt adalah sebagai berikut:

dengan nilai inisiasi awal

$$
\begin{aligned}
& L_{t}=\alpha y_{t}+(1-\alpha)\left(L_{t-1}+T_{t-1}\right) \\
& T_{t}=\beta\left(L_{t}-L_{t-1}\right)+(1-\beta) L_{t-1}
\end{aligned}
$$

$$
L_{m}=\hat{\beta}_{0}+\hat{\beta}_{1} m
$$


dimana

$$
T_{m}=\hat{\beta}_{1}
$$

$L_{t} \quad$ : nilai pemulusan level pada waktu ke-t,

$T_{t} \quad$ : nilai pemulusan tren pada waktu ke-t,

$\alpha \quad$ : nilai parameter pemulusan level,

$\beta \quad$ : nilai parameter pemulusan tren,

$L_{m} \quad$ : nilai inisiasi level,

$T_{m} \quad$ : nilai inisiasi tren,

$\hat{\beta}_{0} \quad$ : intersep,

$\widehat{\beta}_{1}$ : slope,

untuk $t=1,2, \ldots, m$.

Metode robust Holt merupakan metode Holt smoothing berdasarkan pendekatan M-estimation pada regresi terboboti. Pendekatan tersebut merupakan proses cleaning data berpencilan berdasarkan fungsi Huber- $\psi$. Proses cleaning data tersebut dilakukan dengan pemberian bobot yang kecil untuk data pencilan yang bernilai besar. Model pemulusan Holt dengan proses cleaning menjadi:

dimana

$$
\begin{aligned}
& L_{t}=\alpha y_{t}^{*}+(1-\alpha)\left(L_{t-1}+T_{t-1}\right) \\
& T_{t}=\beta\left(L_{t}-L_{t-1}\right)+(1-\beta) T_{t-1}
\end{aligned}
$$

$$
y_{t}^{*}=\psi\left(\frac{y_{t}-F_{t \mid t-1}}{\hat{\sigma}_{t}}\right) \hat{\sigma}_{t}+F_{t \mid t-1}
$$

dengan fungsi Huber dan robust scale,

$$
\begin{gathered}
\psi\left(y_{t}\right)=\left\{y_{t}, \quad j i k a\left|y_{t}\right|<k \operatorname{sign}\left(y_{t}\right) k\right. \text {, selainnya } \\
\hat{\sigma}_{t}^{2}=\lambda_{\sigma} \rho\left(\frac{r_{t}}{\hat{\sigma}_{t-1}}\right) \hat{\sigma}_{t-1}^{2}+\left(1-\lambda_{\sigma}\right) \hat{\sigma}_{t-1}^{2} \\
\rho\left(y_{t}\right)=\left\{c_{k}\left(1-\left(1-\left(\frac{y_{t}}{k}\right)^{2}\right)^{3}\right), j i k a\left|y_{t}\right| \leq k c_{k},\right.
\end{gathered}
$$

Oleh karena itu, model untuk metode pemulusan robust Holt adalah

$$
\begin{gathered}
L_{t}=\alpha \psi\left(\frac{y_{t}-\left(L_{t-1}+T_{t-1}\right)}{\hat{\sigma}_{t}}\right) \hat{\sigma}_{t}+F_{t-1}+T_{t-1} \\
T_{t}=\beta\left(L_{t}-L_{t-1}\right)+(1-\beta) T_{t-1} .
\end{gathered}
$$

dimana

$L_{t} \quad$ : nilai pemulusan level pada waktu ke- $t$,

$T_{t} \quad$ : nilai pemulusan tren pada waktu ke-t,

$\alpha \quad$ : nilai parameter pemulusan level,

$\beta \quad$ : nilai parameter pemulusan tren,

$F_{t \mid t-1} \quad$ : nilai peramalan ke-t pada waktu $t-1$, 
$\hat{\sigma}_{t} \quad$ : nilai estimasi skala galat $r_{t}=y_{t}-F_{t \mid t-1}$,

$\rho \quad$ : fungsi objektif,

$\psi$ (psi) : fungsi Huber (turunan pertama fungsi objektif $\rho$ ).

Peramalan pengamatan ke- $h$, untuk $h=1$ melalui persamaan:

$$
F_{t}=L_{t}+h T_{t}
$$

dimana $F_{t+h \mid t}$ adalah nilai peramalan ke- $h$ pada waktu $t$.

3. Mencari galat dari nilai amatan $y_{t}$ dengan nilai peramalan $F_{t}$.

4. Ulangi langkah 1 sampai 3 sebanyak 1000 kali.

5. Evaluasi kebaikan metode pemulusan.

6. Evaluasi kebaikan metode peramalan yang digunakan yaitu MAD (Mean Absolute Deviation). MAD digunakan untuk mengukur ketepatan nilai dugaan model dalam bentuk rata-rata absolut kesalahan.

$$
M A D=\frac{\sum_{t=1}^{n}\left|y_{t}-\hat{y}_{t}\right|}{n}
$$

dengan $y_{t}$ adalah nilaiamatan ke-t, $\hat{y}_{t}$ adalah nilai dugaan model ke-t dan $n$ adalah banyaknya data/sampel. Semakin kecil nilai-nilai tersebut maka nilai kesalahan dugaan model kecil. Oleh karena itu, apabila nilai kesalahan metode peramalan kecil maka metode peramalan tersebut baik/akurat untuk menduga pengamatan pada masa mendatang.

\section{Hasil dan Pembahasan}

Data deret waktu yang digunakan untuk membandingkan kinerja peramalan dengan metode pemulusan merupakan data simulasi. Data simulasi dibangkitkan sesuai model LLTM dengan parameter level dan tren yang telah ditentukan yaitu sebesar 0.5. Data tersebut terdapat empat kondisi seperti pada Gambar 1. Kondisi pertama adalah CD (clean data) yaitu data bersih dengan galat mengikuti sebaran normal baku dan tanpa dipengaruhi oleh pencilan. Kondisi kedua adalah SO (symmetric outliers) yaitu data dipengaruhi pencilan simetrik dengan $95 \%$ galat mengikuti sebaran normal baku dan $5 \%$ mengikuti sebaran $\mathrm{N}(0,20)$. Pencilan simetrik tersebut memiliki maksud yang sama dengan pengamatan yang lain tetapi memiliki ragam yang besar. Kondisi ketiga yaitu AO (asymmetric outliers) yaitu data amatan yang dibangkitkan memiliki ragam yang sama tetapi nilai mean berbeda dari sebagian data amatan sehingga menghasilkan pencilan asimetrik. Kondisi keempat yaitu FT (fat-tailed data) mengikuti sebaran t-students. Data simulasi yang dibangkitkan yaitu sebanyak 105 data. Akan tetapi, kondisi SO dan AO pada amatan ke-101 sampai dengan 105 tidak disertakan pencilan dalam deret perkiraan. Pada Gambar 1 juga menunjukkan bahwa data yang dibangkitkan berpola tren naik untuk kondisi $\mathrm{CD}, \mathrm{SO}$, 


\section{AO, dan FT.}

Data deret waktu yang dibangkitkan sebanyak 105 data deret waktu dengan 1000 kali pengulangan dibagi menjadi 100 data training dan 5 data testing. Data training digunakan untuk mengetahui model yang dapat memprediksi data baru, sedangkan data testing digunakan untuk mengetahui prediksi dari model yang dibentuk data training sudah sesuai. Data training tersebut dilakukan peramalan 5 periode ke depan data deret waktu dengan metode pemulusan Holt dan robust Holt. Data peramalan yang dihasilkan data training dibandingkan dengan dengan data testing sehingga diperoleh nilai kesalahan atau galat perkiraan peramalan. Hasil galat peramalan dievaluasi berdasarkan nilai MAD. Evaluasi kebaikan metode pemulusan terlihat pada nilai MAD yang lebih kecil.

Gambar 2 menunjukan bahwa nilai MAD untuk data training kondisi CD yang dihasilkan dari metode pemulusan Holt lebih baik dibandingkan dengan metode pemulusan robust Holt yaitu terlihat dari nilai median yang lebih kecil. Hal tersebut juga ditunjukan pada Gambar 3 bahwa dalam 1000 kali ulangan pada metode pemulusan robust Holt terjadi 240 kali ulangan nilai MAD lebih kecil dibandingkan dengan metode pemulusan Holt. Metode pemulusan Holt terjadi 760 kali ulangan lebih kecil dibandingkan dengan metode pemulusan robust Holt. Nilai MAD pada Gambar 2 untuk data testing kondisi CD metode pemulusan Holt hampir sebanding dengan metode pemulusan robust Holt terlihat dari nilai median yang hampir sama. Selain itu, pada Gambar 3 menunjukan bahwa dalam 1000 kali ulangan mendapatkan nilai MAD yang lebih kecil untuk metode pemulusan robust Holt sebanyak 468 kali, sedangkan metode pemulusan Holt sebanyak 532 kali nilai MAD yang lebih kecil. 

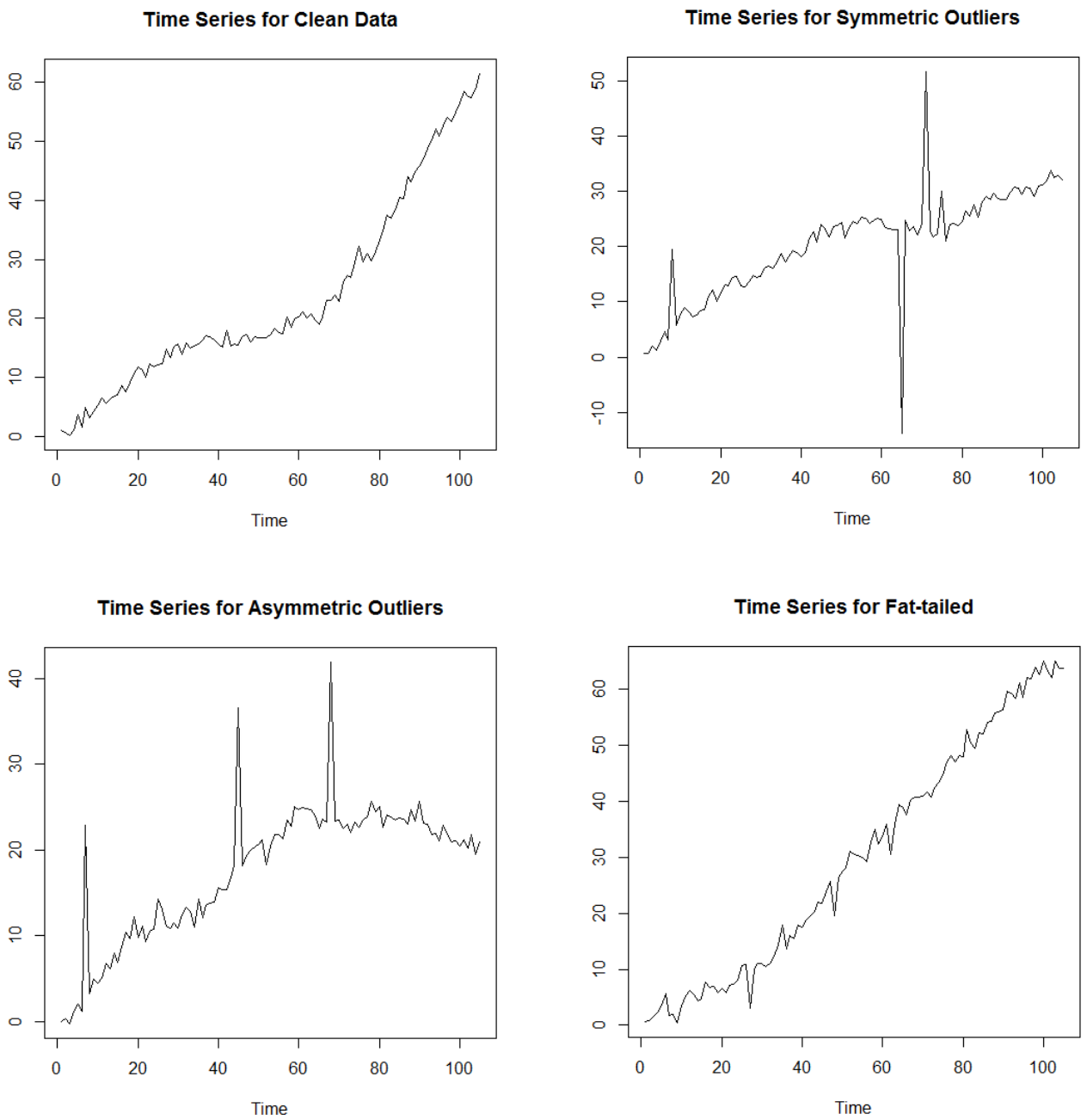

Gambar 1: Contoh plot 105 data deret waktu yang dibangkitkan sesuai dengan skema simulasi CD (kiri atas), SO (kanan atas), AO (kiri bawah) dan FT (kanan bawah).
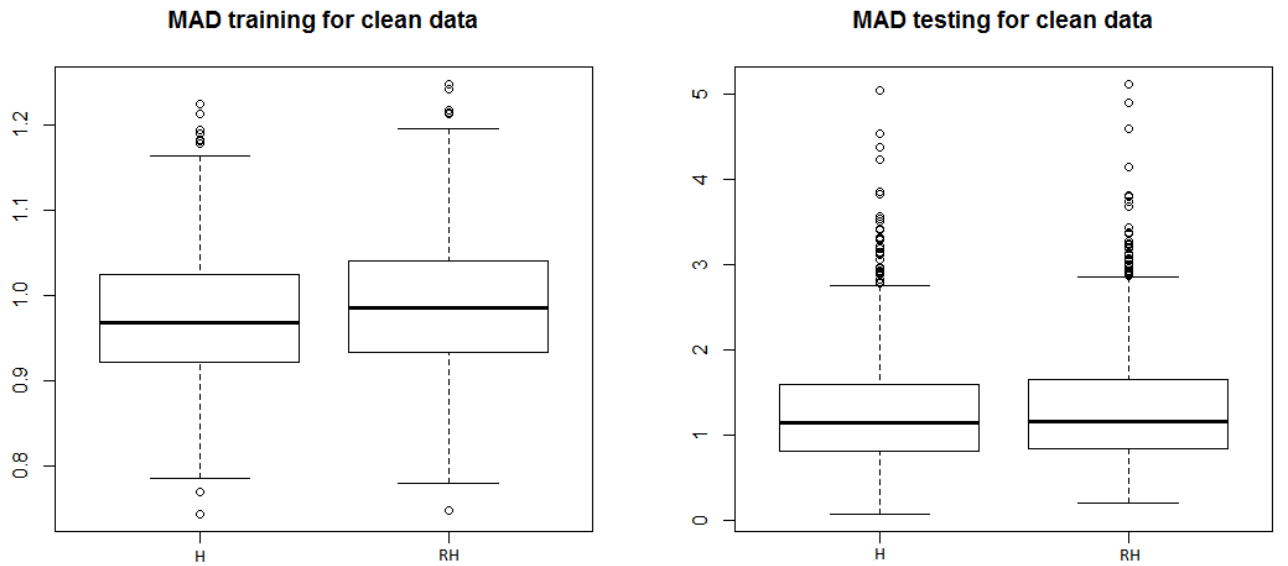

Gambar 2: Boxplot nilai MAD untuk CD 


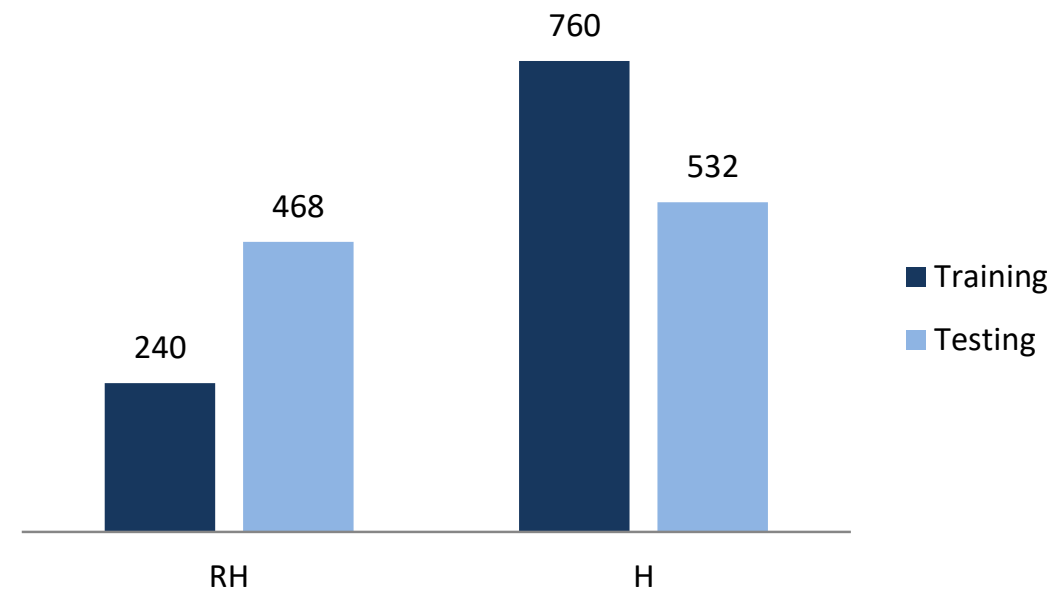

Gambar 3: Hasil evaluasi kebaikan metode RH dibandingkan dengan metode $\mathrm{H}$ dalam 1000 kali pengulangan $\mathrm{CD}$

Gambar 4 menunjukan nilai MAD untuk data training dan testing kondisi SO metode pemulusan robust Holt lebih baik dibandingkan dengan dengan metode pemulusan Holt terlihat dari nilai median yang lebih kecil dibandingkan dengan metode pemulusan Holt. Selain itu, Gambar 5 juga menjelaskan bahwa nilai MAD untuk data training metode pemulusan robust Holt yang lebih kecil dibandingkan dengan metode pemulusan Holt terjadi sebanyak 982 kali ulangan dan nilai MAD untuk data testing terjadi sebanyak 683 kali ulangan. Nilai MAD pada metode pemulusan Holt untuk data training yang lebih kecil dibandingkan dengan metode pemulusan robust Holt terjadi sebanyak 18 kali ulangan dan untuk data testing terjadi sebanyak 317 kali ulangan dalam 1000 kali pengulangan.
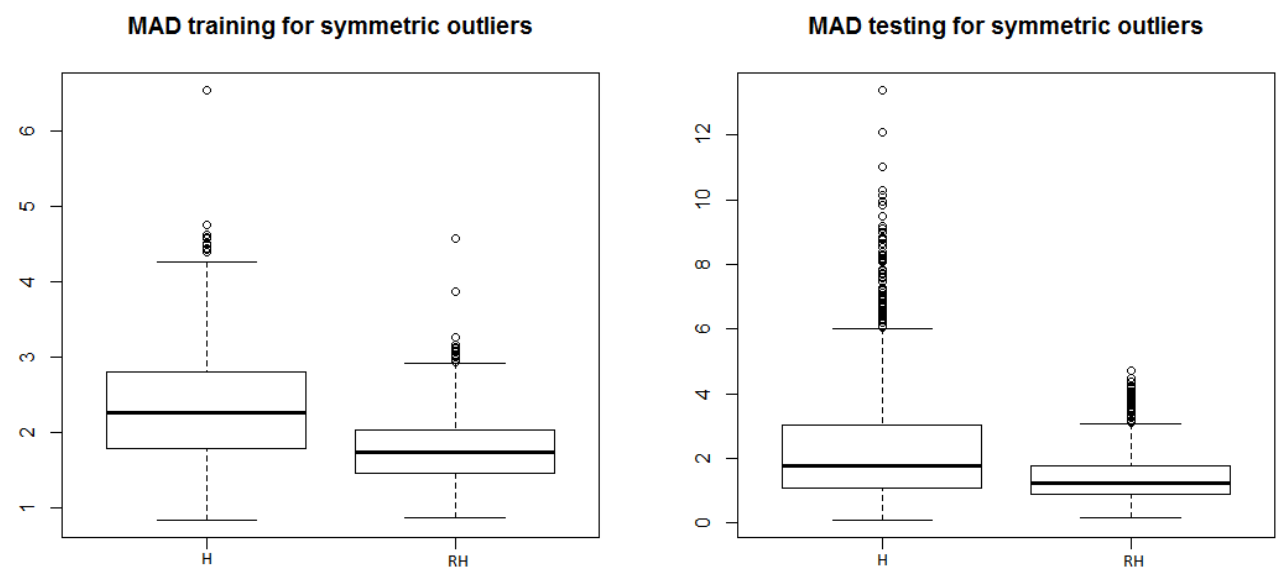

Gambar 4: Boxplot nilai MAD untuk SO 


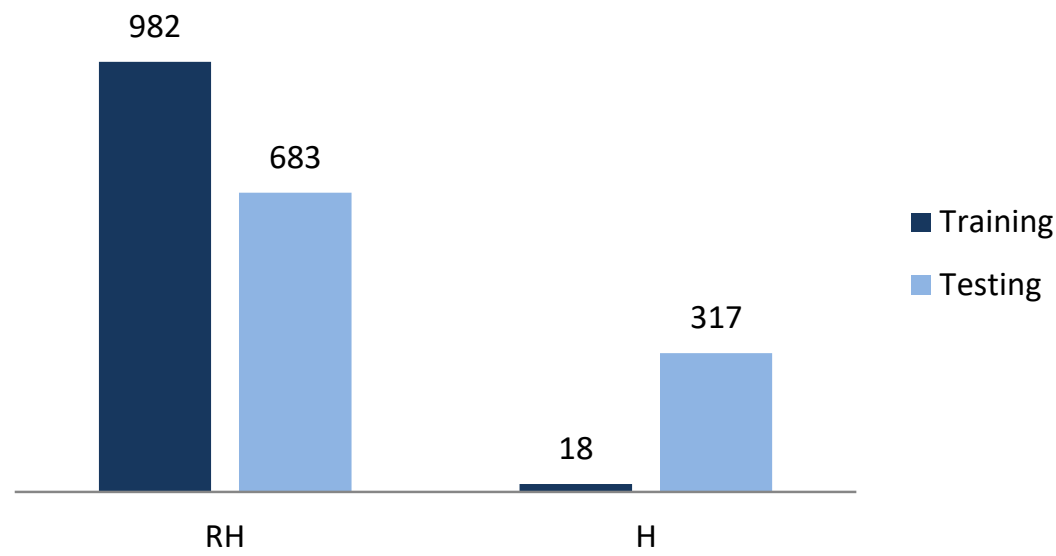

Gambar 5: Hasil evaluasi kebaikan metode $\mathrm{RH}$ dibandingkan dengan metode $\mathrm{H}$ dalam 1000 kali pengulangan SO

Nilai MAD untuk data training dan data testing kodisi AO pada Gambar 6 menunjukan nilai median metode pemulusan robust Holt lebih kecil dibandingkan dengan metode pemulusan Holt. Hal tersebut juga terlihat pada Gambar 7 bahwa metode pemulusan robust Holt untuk data training dan data testing kondisi AO lebih baik dengan kejadian nilai MAD yang lebih kecil sebanyak 993 kali ulangan dan 738 kali ulangan dalam 1000 kali pengulangan. Selain itu, Gambar 7 menunjukan bahwa nilai MAD metode pemulusan Holt yang lebih kecil dibandingkan dengan metode robust Holt untuk data testing dan testing kondisi $A O$ terjadi sebanyak 7 kali ulangan dan 262 kali ulangan dalam 1000 kali pengulangan.
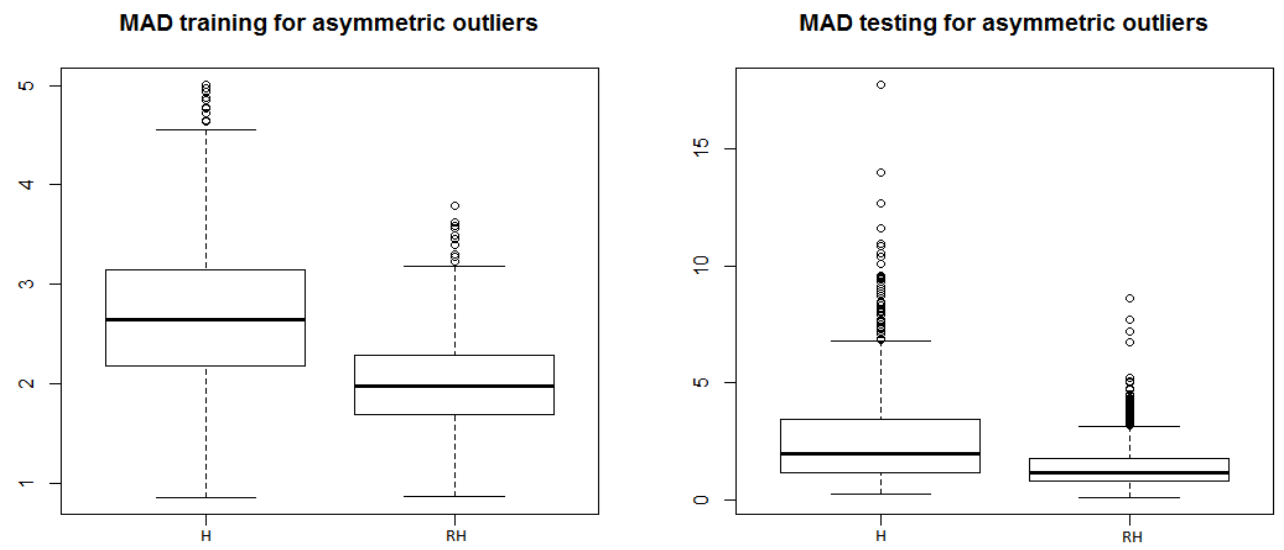

Gambar 6: Boxplot nilai MAD untuk AO 


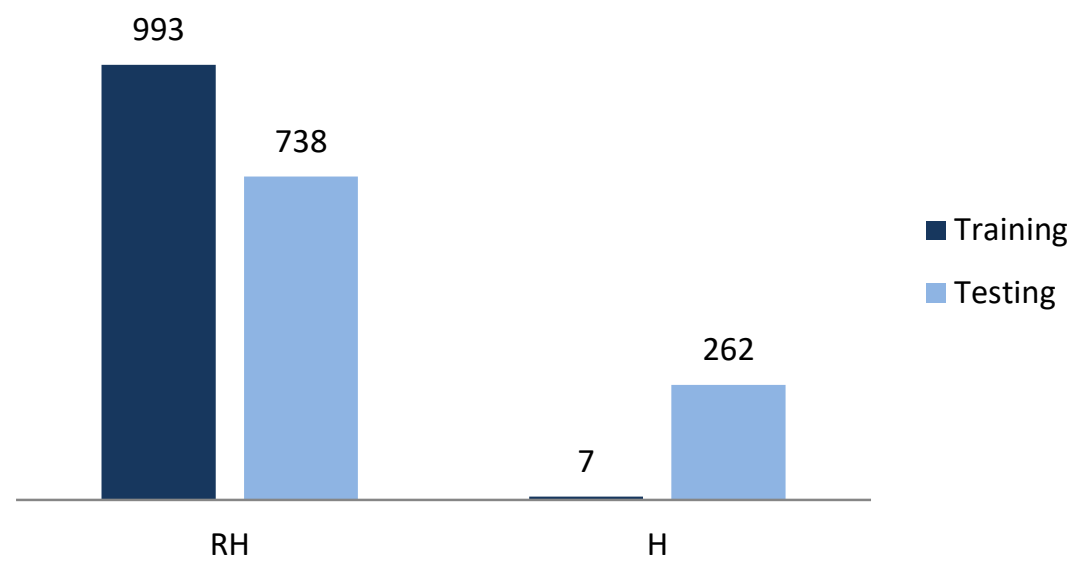

Gambar 7: Hasil evaluasi kebaikan metode $\mathrm{RH}$ dibandingkan dengan metode $\mathrm{H}$ dalam 1000 kali pengulangan $\mathrm{AO}$

Gambar 8 menunjukan nilai MAD metode pemulusan Holt dan robust Holt untuk data training dan testing kondisi FT hampir sebanding kebaikan metode tersebut terlihat dari nilai median yang hampir sama. Akan tetapi, banyaknya sebaran data nilai MAD yang terdapat diluar boxplot lebih sedikit untuk metode pemulusan robust Holt dibandingkan dengan metode pemulusan Holt menunjukan bahwa metode pemulusan robust Holt lebih baik. Hal tersebut juga terlihat pada Gambar 9 bahwa metode pemulusan robust Holt untuk data training dan data testing kondisi FT dalam 1000 kali ulangan terjadi 611 kali ulangan dan 524 kali ulangan nilai MAD yang lebih kecil. Nilai MAD untuk data training dan testing kondisi FT metode pemulusan Holt yang lebih kecil dibandingkan metode pemulusan robust Holt terjadi sebanyak 389 kali ulangan dan 476 kali untuk dalam 1000 kali pengulangan.
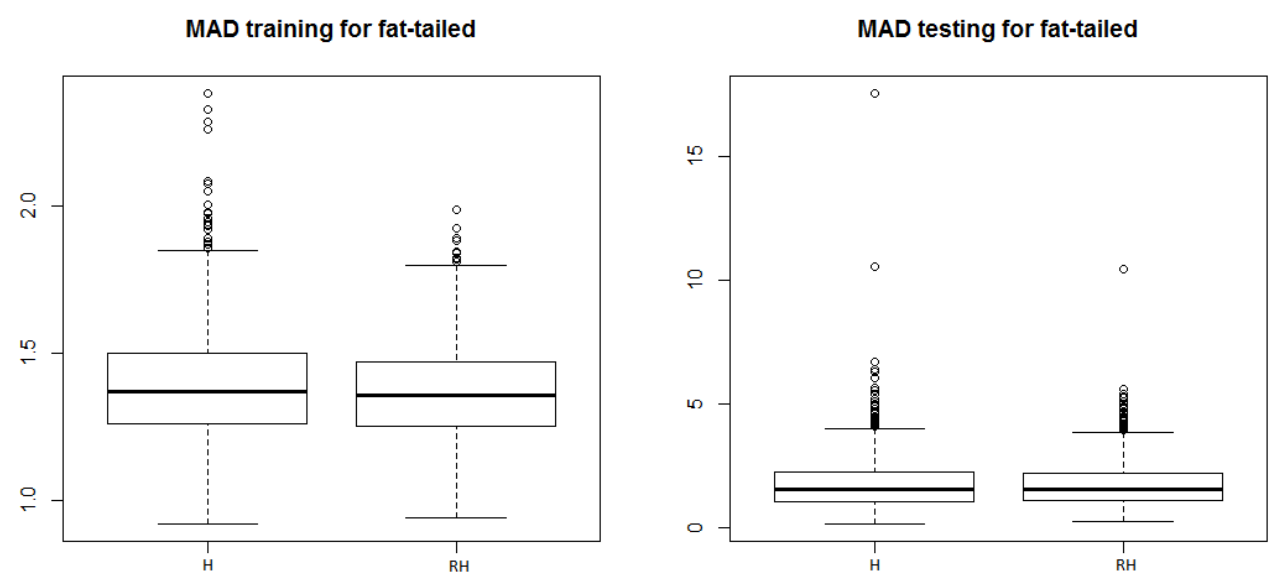

Gambar 8: Boxplot nilai MAD untuk FT 


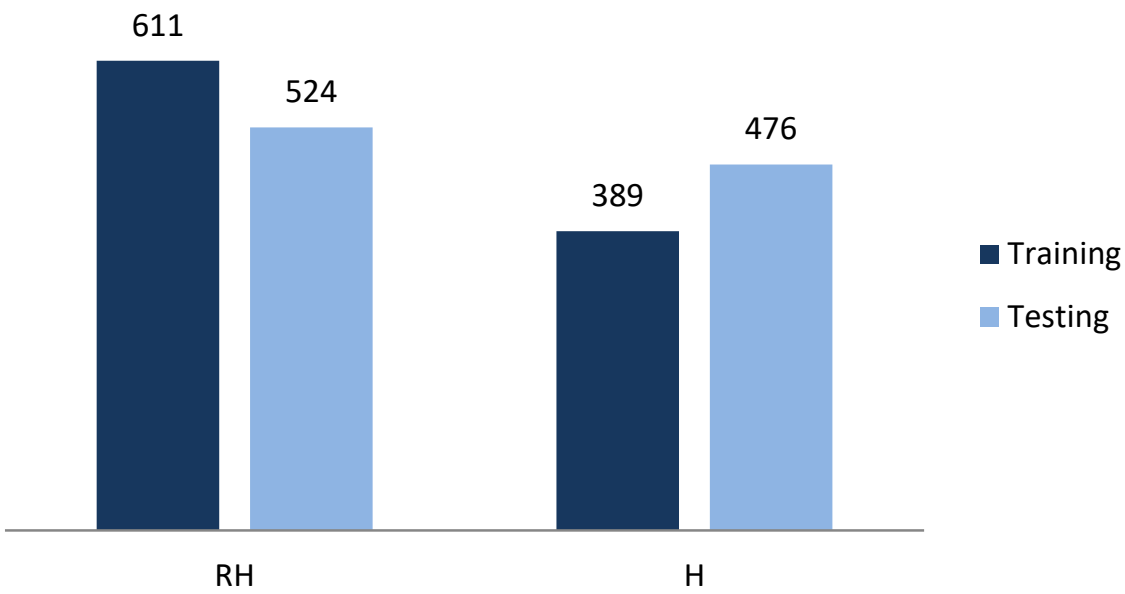

Gambar 9: Hasil evaluasi kebaikan metode $\mathrm{RH}$ dibandingkan dengan metode $\mathrm{H}$ dalam 1000 kali pengulangan FT
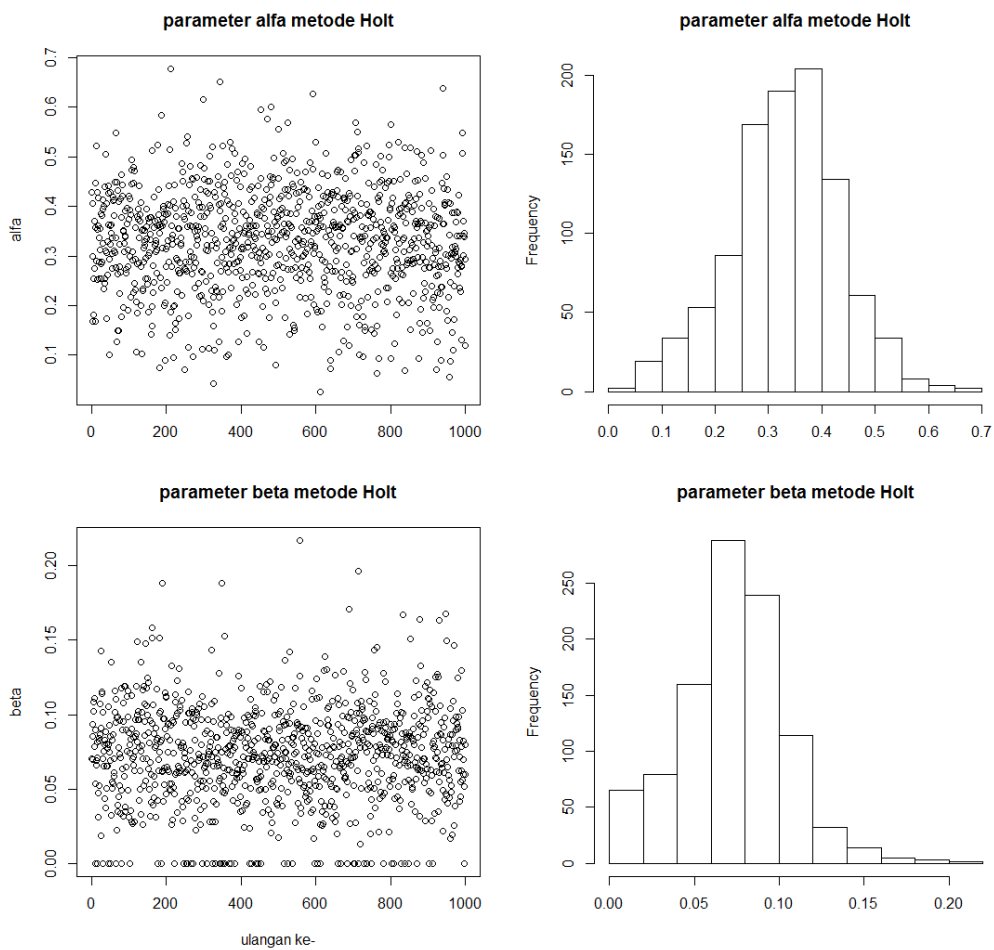

Gambar 10: Plot pendugaan parameter pemulusan kondisi CD metode pemulusan Holt 

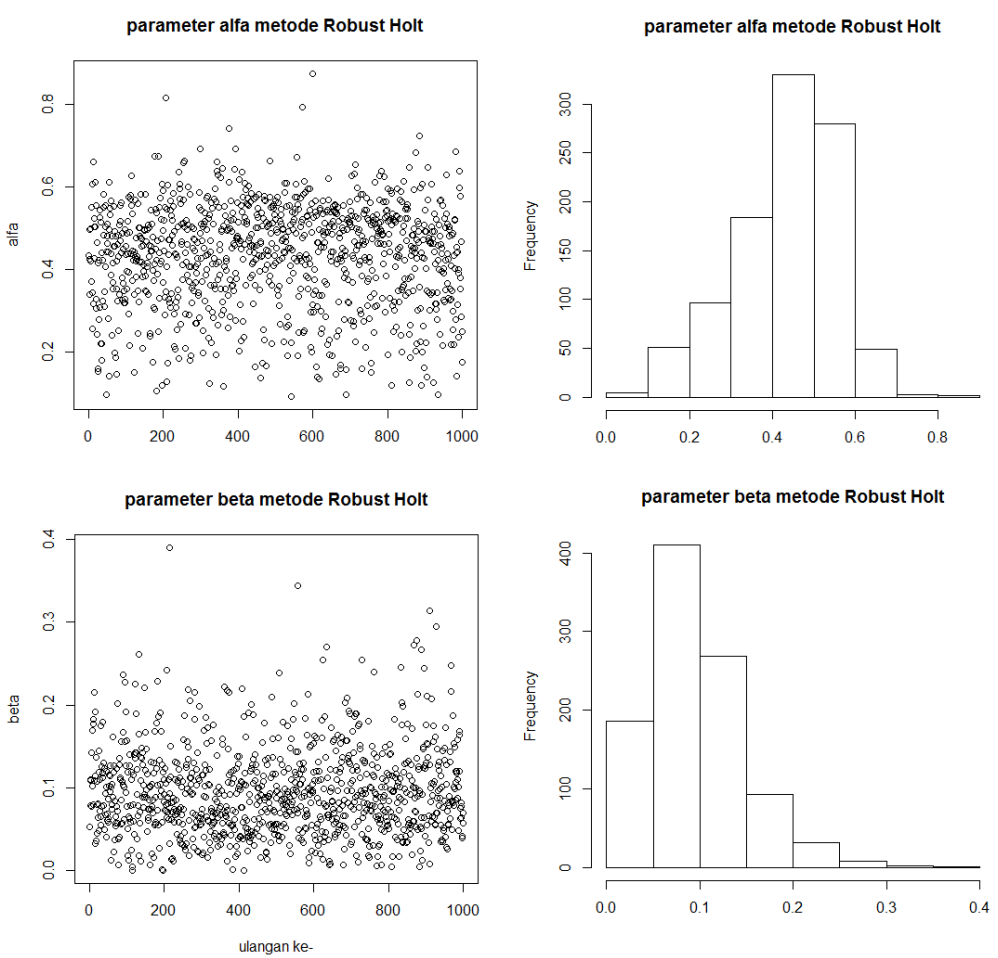

Gambar 11: Plot pendugaan parameter pemulusan kondisi CD metode pemulusan robust Holt

Setelah dilakukan peramalan pada data simulasi deret waktu juga didapatkan parameter dugaan pemulusan yaitu alfa untuk parameter pemulusan level dan beta untuk parameter pemulusan tren. Gambar 10 menunjukan pada metode pemulusan Holt untuk kondisi CD dugaan parameter alfa yang dihasilkan paling banyak diantara 0.35-0.40 dan dugaan parameter beta yang dihasilkan paling banyak diantara 0.050.10. Gambar 11 menunjukan pada metode pemulusan robust Holt kondisi CD dugaan parameter alfa yang dihasilkan paling banyak diantara 0.40-0.50 dan dugaan parameter beta yang dihasilkan paling banyak diantara 0.05-0.10. Gambar 12 menunjukan pada metode pemulusan Holt kondisi SO dugaan parameter alfa yang dihasilkan paling banyak diantara 0.00-0.05 dan dugaan parameter beta yang dihasilkan paling banyak diantara 0.00-0.01. Pada Gambar 13 menunjukan dugaan parameter alfa yang dihasilkan metode pemulusan robust Holt kondisi SO paling banyak diantara 0.40-0.50 dan dugaan parameter beta yang dihasilkan paling banyak diantara 0.05-0.10. 

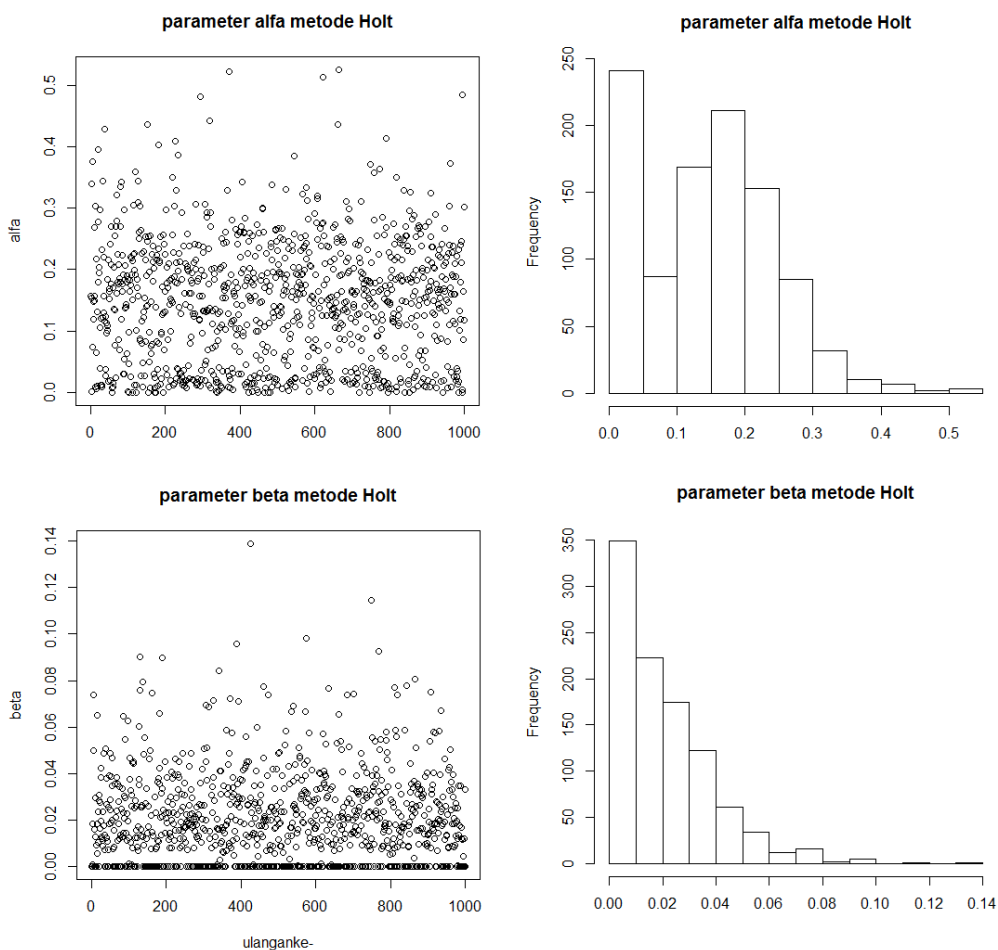

Gambar 12: Plot pendugaan parameter pemulusan kondisi SO metode pemulusan Holt

Gambar 14 menunjukan pada metode pemulusan Holt kondisi AO dugaan parameter alfa yang dihasilkan paling banyak diantara 0.00-0.05 dan dugaan parameter beta yang dihasilkan paling banyak diantara 0.00-0.01. Selain itu, Gambar 15 menunjukan dugaan parameter alfa metode pemulusan robust Holt kondisi AO yang dihasilkan paling banyak diantara $0.425-0.450$ dan dugaan parameter beta yang dihasilkan paling banyak diantara 0.05-0.10. Gambar 16 menunjukan pada metode pemulusan Holt kondisi FT dugaan parameter alfa yang dihasilkan paling banyak diantara 0.20-0.25 dan dugaan parameter beta yang dihasilkan paling banyak diantara 0.050-0.052, sedangkan pada Gambar 17 menunjukan dugaan parameter alfa pada metode pemulusan robust Holt kondisi FT yang dihasilkan paling banyak diantara 0.45 0.50 dan dugaan parameter beta yang dihasilkan paling banyak diantara 0.05-0.10. 

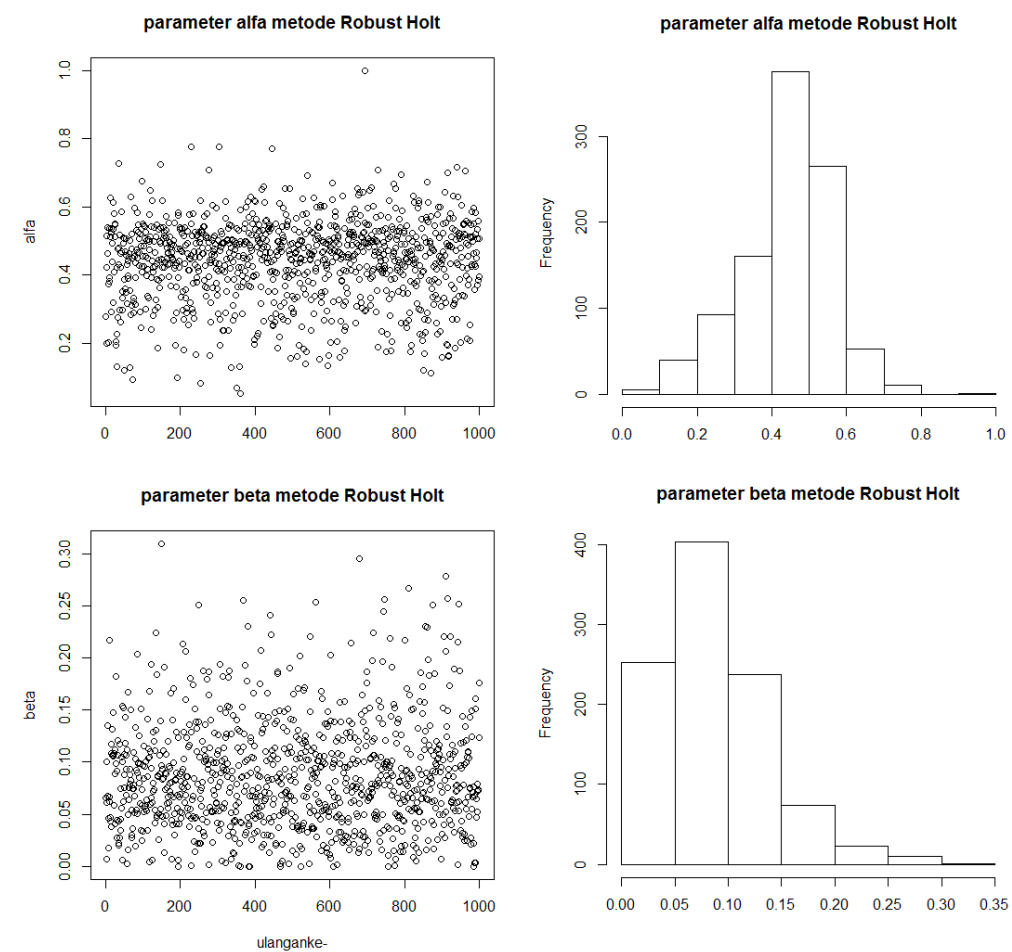

Gambar 13: Plot pendugaan parameter pemulusan kondiai SO metode pemulusan robust Holt
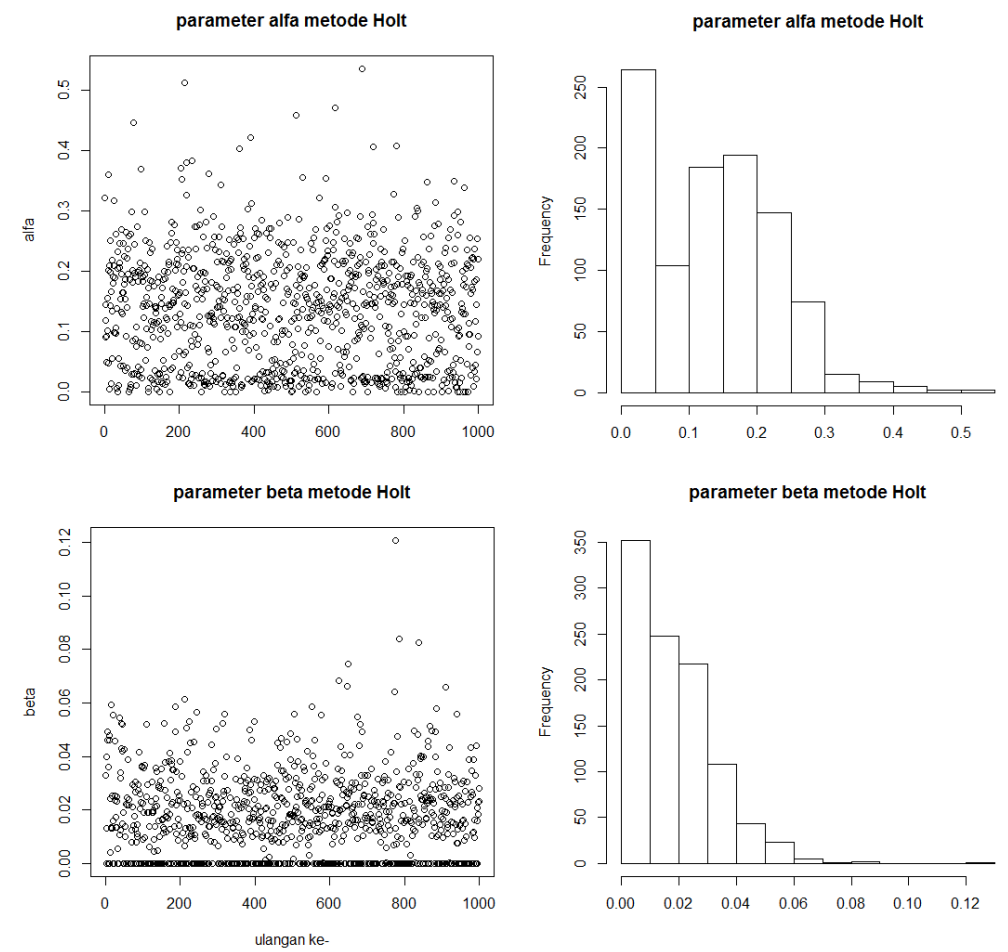

Gambar 14: Plot pendugaan parameter pemulusan kondiai AO metode pemulusan Holt 

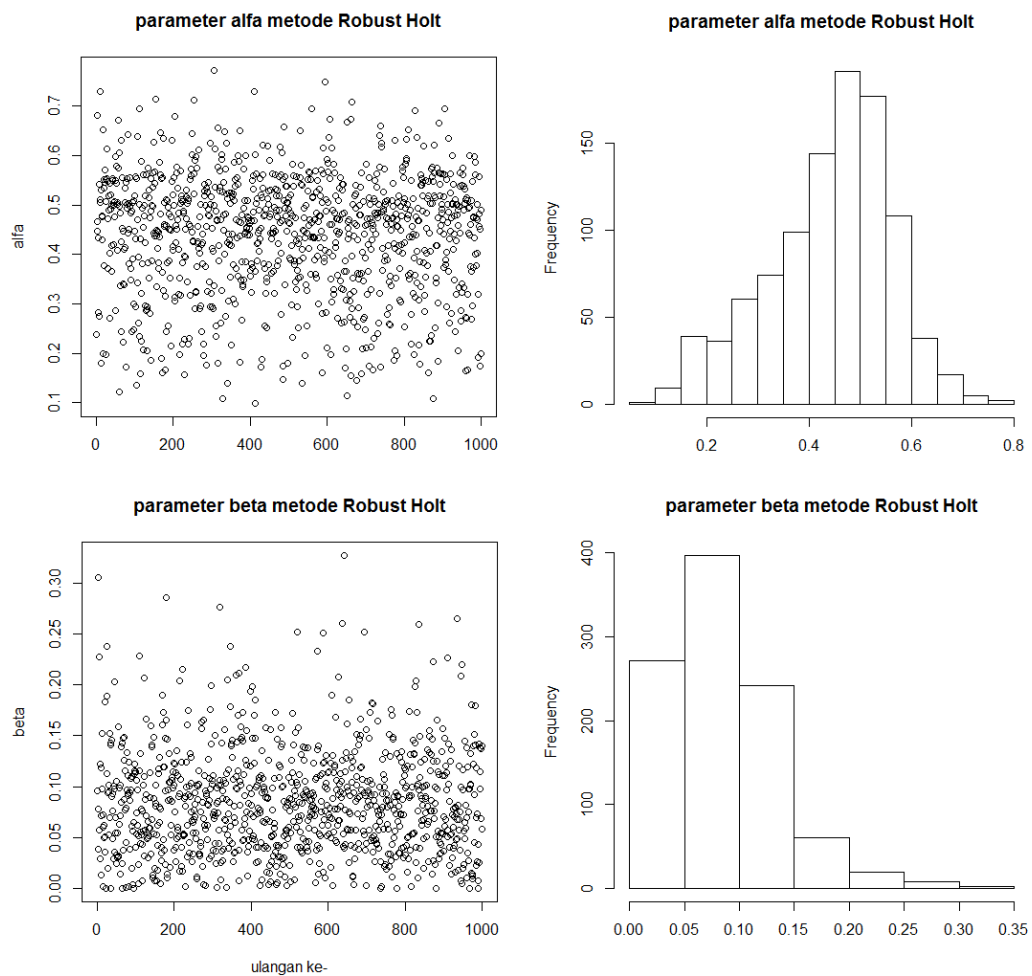

Gambar 15: Plot pendugaan parameter pemulusan kondiai AO metode pemulusan robust Holt
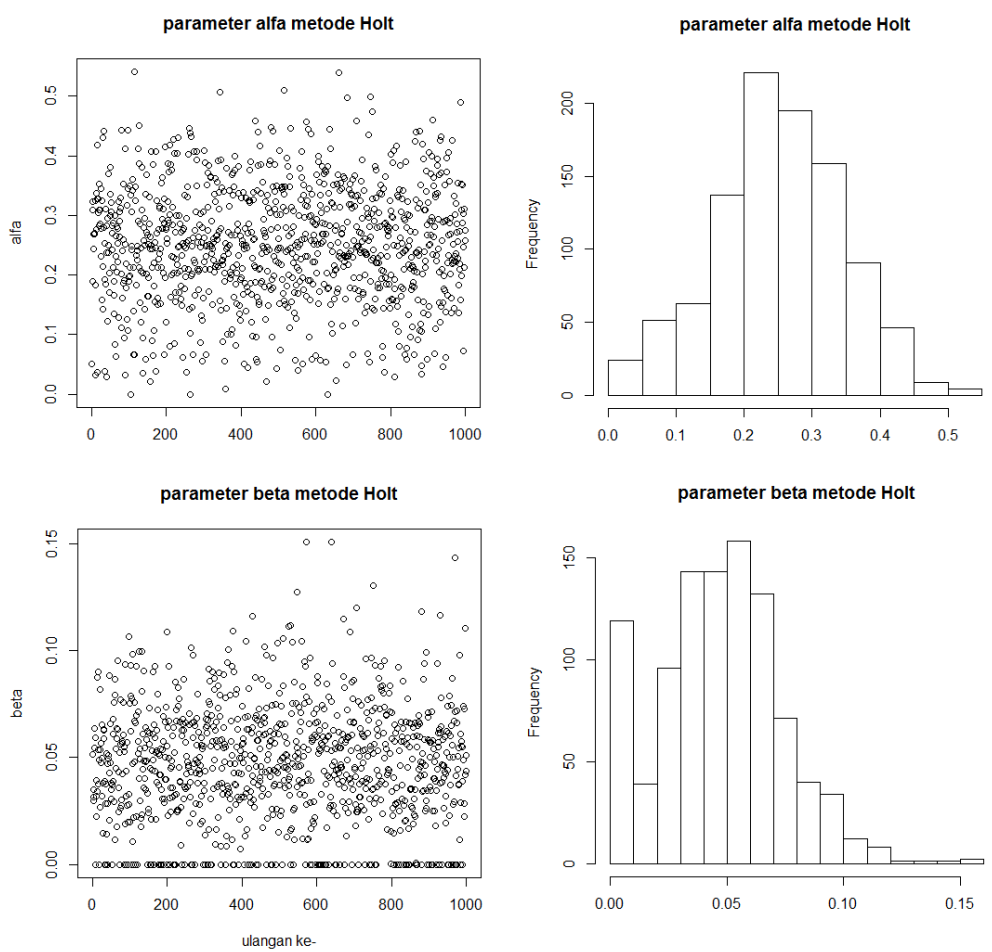

Gambar 16: Plot pendugaan parameter pemulusan kondiai FT metode pemulusan Holt 

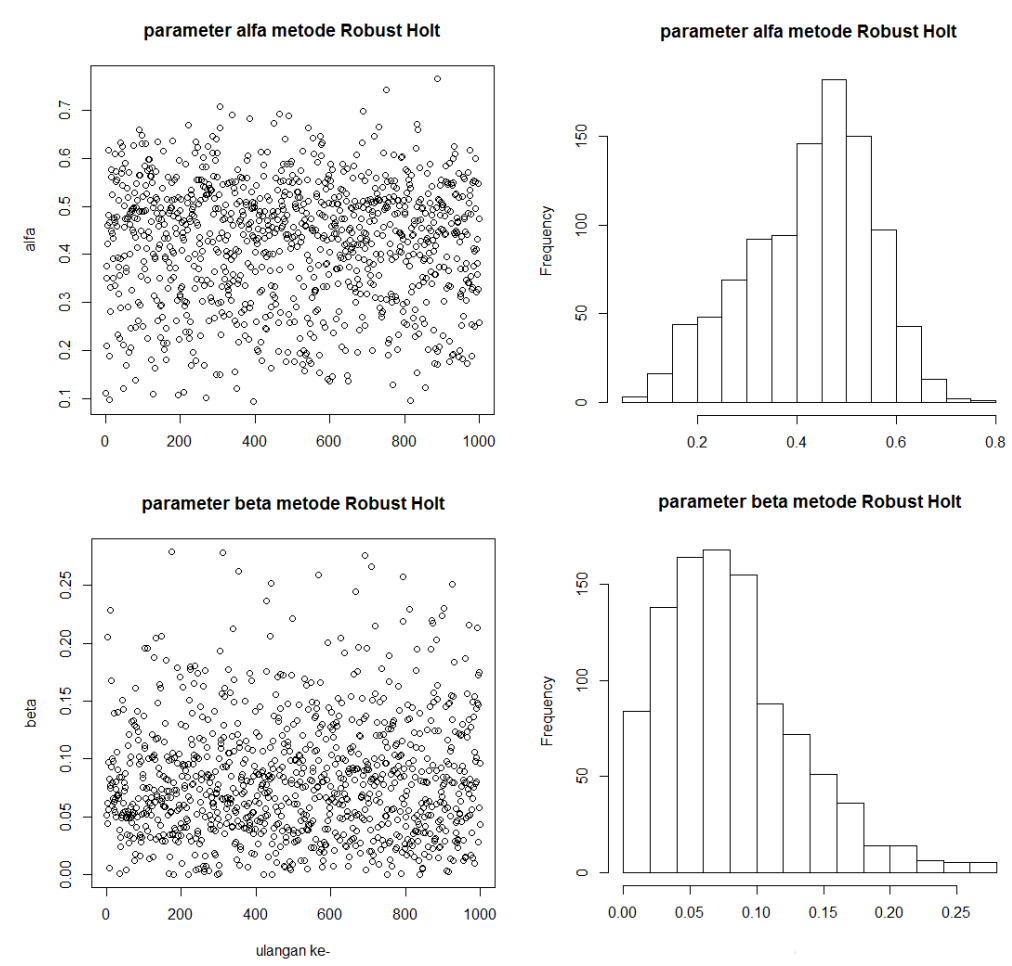

Gambar 17: Plot pendugaan parameter pemulusan kondiai FT metode pemulusan robust Holt

\section{Simpulan}

Penanganan pencilan pada data deret waktu menggunakan metode pemulusan robust Holt yang dilakukan pada data simulasi lebih baik digunakan dibandingkan dengan metode pemulusan Holt dilihat dari evaluasi kebaikan metode yaitu MAD. Nilai MAD yang dihasilkan metode pemulusan robust Holt lebih kecil dibandingkan dengan meode pemulusan Holt untuk data berpencilan simetrik maupun asimetrik, sedangkan nilai MAD untuk data tidak berpencilan dihasilkan nilai yang lebih kecil untuk metode pemulusan Holt. Hal tersebut terlihat dari nilai median dalam boxplot yang lebih kecil. Selain itu, metode pemulusan Holt untuk data training kondisi CD dalam 1000 kali pengulangan dihasilkan nilai MAD yang lebih kecil dibandingkan dengan metode pemulusan robust Holt, sedangkan pada data testing nilai MAD yang lebih kecil untuk kedua metode pemulusan hampir sama dalam 1000 kali pengulangan. Kondisi SO untuk data training dan data testing nilai MAD yang lebih kecil dalam 1000 kali pengulangan adalah metode pemulusan robust Holt. Kondisi $\mathrm{AO}$ untuk data training maupun data testing nilai MAD yang lebih kecil dalam 1000 kali pengulangan adalah metode pemulusan robust Holt. Kondisi FT juga didapatkan hasil untuk data training nilai MAD yang lebih kecil dalam 1000 kali pengulangan adalah metode pemulusan Holt, sedangkan pada data testing nilai MAD yang lebih kecil untuk kedua metode pemulusan hampir sama dalam 1000 kali pengulangan. 


\section{Daftar Pustaka}

Cipra, T. (1992). Robust exponential smoothing. Journal of Forecasting, 11(1): 57-69.

Croux, C., Gelper, S., \& Fried, R. (2008). Computational aspects of robust Holt-Winters smoothing based on M-estimation. Applications of Mathematics, 53(3): 163-176.

Gelper, S., Fried, R., \& Croux, C. (2010). Robust forecasting with exponential and HoltWinters smoothing. Journal of Forecasting, 29(3): 285-300.

Kirkendall, N. J. (1992). Monitoring for outliers and level shifts in Kalman filter implementations of exponential smoothing. Journal of Forecasting, 11(6): 543-560.

Koehler, A. B., Snyder, R. D., Ord, J. K., \& Beaumont, A. (2012). A study of outliers in the exponential smoothing approach to forecasting. International Journal of Forecasting, 28(2): 477-484.

Montgomery, D. C. (2007). Introduction to statistical quality control. John Wiley \& Sons.

Taylor, J. W. (2007). Forecasting daily supermarket sales using exponentially weighted quantile regression. European Journal of Operational Research, 178(1): 154-167. 